\title{
Industrial Applications of Clay Materials from Ghana (A Review)
}

\author{
R. B. ASAMOAH ${ }^{1}$, E. NYANKSON ${ }^{1}$, E. ANNAN ${ }^{1}$, B. AGYEI-TUFFOUR ${ }^{1}$, J. K. EFAVI', \\ K. KAN-DAPAAH ${ }^{2}$, V. A. APALANGYA ${ }^{3}$, L. N. W. DAMOAH ${ }^{1}$, D. DODOO-ARHIN ${ }^{1}$, \\ E. K. TIBURU ${ }^{2}$, S. K. KWOFIE ${ }^{2}$, B. ONWONA-AGYEMAN and A.YAYA ${ }^{1,4 *}$
}

1'Department of Materials Science \& Engineering, CBAS, University of Ghana, Legon, Ghana. ${ }^{2}$ Department of Biomedical Engineering, CBAS, University of Ghana, Legon, Ghana.

${ }^{3}$ Department of Food Process Engineering, CBAS, University of Ghana, Legon, Ghana. ${ }^{4}$ Institut des Matériaux Jean Rouxel (IMN), UMR 6502, CNRS, Université de Nantes, France. ${ }^{*}$ Corresponding author E-mail: ayaya @ ug.edu.gh

http://dx.doi.org/10.13005/ojc/340403

(Received: June 29, 2018; Accepted: July 30, 2018)

\begin{abstract}
Clay minerals are phyllosilicate groups naturally found in soils in all parts of the world. They have proven to be among the most essential industrial minerals because of their unique physicochemical properties and versatile applications within a wide range of fields including ceramics, construction, and environmental remediation, biomedical as well as cosmetics. Clay minerals are also primary to the production of other materials such as composite for secondary applications. In Ghana, clay mineral deposits are commonly found in several areas including soil horizons as well as geothermal fields and volcanic deposits, and are formed under certain geological conditions. This review seeks to explore the geographical occurrence and discusses the current uses of various local clay materials in Ghana in order to highlight opportunities for the utilization of these materials for other applications.
\end{abstract}

Keywords: Clay minerals, Ceramics, Properties, Application, Ghana.

\section{INTRODUCTION}

Though clay deposits are ubiquitous in Ghana and have important domestic applications, their physicochemical properties for such application has not been fully explored. ${ }^{1}$ The importance of clay is demonstrated mainly in various applications that are documented as well as those classified as traditional uses without prior scientific knowledge. ${ }^{2}$ In Ghana, the use of clay extend from traditional uses such as geophagy to contemporary use in pottery, construction and water purification. Clay is overly distributed and each deposit has unique properties that can be tailored towards a particular application. The clay deposits in the regions are given in Fig. 1. According to Kesse (1985), clays are mainly of either alluvial or residual sources and are formed from rock dissolution and sedimentation. ${ }^{3}$ The deposits may be found covered by a few meters thickness of superficial soil such as humus. The 
various deposits of clay shown in Fig. 1, consist of different kinds of clay minerals as studied by the Ghana Geological Survey Department-Ceramics Laboratory (1999). According to the study, clay deposits possesses properties relating to weight shrinkage, moisture content, plasticity and raw colour. ${ }^{4}$ Structurally, they are natural layered material primarily occurring in soils with relatively smaller particle size components. ${ }^{5}$ The chemical structures of clay minerals are dominated by arrays of planar $\mathrm{SiO}_{4}$ and $\mathrm{Al}_{2} \mathrm{O}_{3}$ structural hydroxyls and water. Also, different materials such as feldspar, mica and quartz, are mostly produced from weathered rocks and other volcanic activities. These rocks are formed under high temperatures and pressure beneath the earth surface. ${ }^{6}$ The dissolution of primary rock minerals release ions which crystalize in aqueous environment for the formation of these clays. Even though clay are mostly associated with soil, the components of clay is generally porous and normally filled with water and air compared to ordinary soil which is amorphous in nature and disaggregated. ${ }^{7}$ Other contaminants may also complicate the formation of clay and this may result in the non-homogeneous nature of the mineral particles. An important adage of the association of clay with soil is that mineral particles can diffuse into the pore structures of the clay materials hence making it plastic and introduces different properties and application for the material. ${ }^{8}$ They also have varying water content and this enables their swelling ability which results in their plasticity characteristics. ${ }^{9,10}$ The properties of clay also allows molding and shaping leading to cohesiveness in the material. ${ }^{11}$ The properties of clay materials may be further impacted by modifying their structure through processes such as composite formulations. Modified clays consequently result in a charge and surface properties suitable for nanocomposites, organoclays, acid and induced clays synthesis. ${ }^{12,13}$ Clay-polymer composites have also altered chemical constituents and structure of nanoclays for various applications. The applications of modified clay just as natural clay are greatly achieved by knowledge of the modification procedure and its associated properties. $^{14}$

The applications of clays are numerous spanning across disciplines such as geology, construction, environmental remediation, pharmaceutical and cosmetics industries. These applications continue to improve through synthesis of other materials such as zeolites and clay mineralpolymer nano-composites using clay as template. ${ }^{15}$ In Ghana, clay mineral deposits are densely dispersed across the entire land area. Every region in Ghana has a measure of clay deposits. ${ }^{16}$ The local clays differ by colour and other properties such as cohesion, viscosity and fired strength. The geographical location for each clay materials confer unique physico-chemical properties which ultimately determines the type of material produced and its application. ${ }^{17}$ This paper reviews local clays in Ghana and their diverse applications. The current review provides the characteristic of clay minerals deposits in the country to relate their usefulness for the ceramics, environmental remediation and healthcare disciplines.

\section{Synthesis Methods; Using Clay as Template}

The properties of clay minerals are also subject to change through modification. ${ }^{19}$ The structure and composition of clay minerals can be altered to obtain diverse functionalities. Kaolinite consist of alternating octahedral and silicate tetrahedral structures. The tetrahedral sheets $\left(\mathrm{SiO}_{4}\right)$ and octahedral sheets $\left(\mathrm{AlO}_{2}(\mathrm{OH})_{4}\right)$ are bonded by Van der Waals forces and hydrogen bonding. ${ }^{20}$ Cheng (1998) ${ }^{21}$, modified the structure of kaolin by the introduction of potassium acetate in the interlayer spacing of kaolin clay mineral. Potassium acetate breaks the interconnecting Van der Waals forces and allows the formation of hydrogen bonding between adjacent layers. The interlayer spacing of kaolin then increases from about $7.8 \AA$ to about $14.70 \AA .{ }^{21}$ Grafting reactions of covalent bonds can sequentially take place between the hydroxyl of octahedral and organic molecules (Al-O-C) which consequently alters the properties of clay mineral such as thermal, chemical, surface area, etc..22 The modified clay has characteristics which is significantly different from the unmodified counterpart. For instances, properties such as clay porosity may be altered. The change in clay porosity influences its use in applications such as adsorption of organic compounds. ${ }^{23}$ lon exchange is a preferred medium for modifying clay with organic molecules. Cations are not strongly bonded to clay minerals hence small molecule cations can replace them. Surfactants containing short hydroxyl groups, benzyl, aliphatic chains and long ones are used to increase basal spacing between layers. ${ }^{24}$ The ion exchange, 
changes surface properties of clay minerals which can act as adsorbents. Intercalation of clay by organic molecules has led to well defined materials of extreme structural and chemical performance for example in clay-polymer nanocomposite. Clay minerals can also be modified through acid-induced and salt-induced methods which are good adsorbents in catalysis for degrading oil.
Thermally and mechanically induced clay is another form of modified clay. Local clay minerals in Ghana have been modified through a number of processes such as hydrothermal synthesis ${ }^{15}$ and composite preparations $\mathbf{s}^{5,12,13,14}$ to create other materials such as zeolites, electroporcelain insulators, etc. Additionally, modified clays can have applications in medicine, energy and environment.

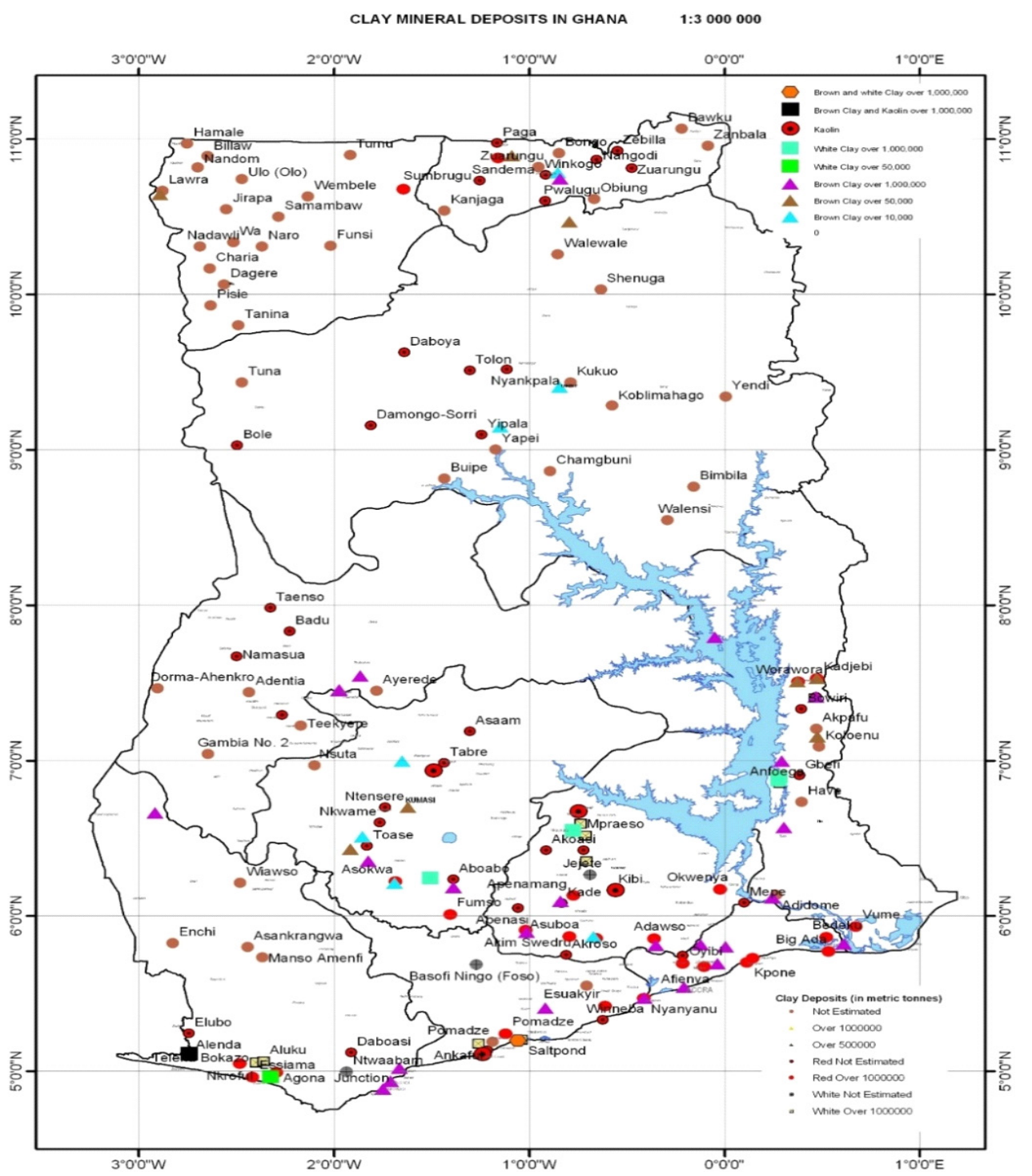

Fig. 1. A map of the Clay mineral deposits in Ghana. Source: Geological Survey Department, Ghana, showing the clay deposits spread across the entire land area. The country has $238,535 \mathrm{~km} 2$ land size with significant amount of clay reserves in commercial quantities ${ }^{18}$

\section{Clay Minerals distribution in Ghana}

The clay minerals in Ghana are deposited across all the regions in many areas of the entire land mass, Table 1. According to the findings, the clays in Ghana are mainly of either alluvial or residual sources. Clays are formed from rock dissolution and sedimentation and may cover few meters from the superficial soil; normally humus. ${ }^{27}$ 
Table 1: Clay Deposits in Ghana grouped by region and area $^{3}$

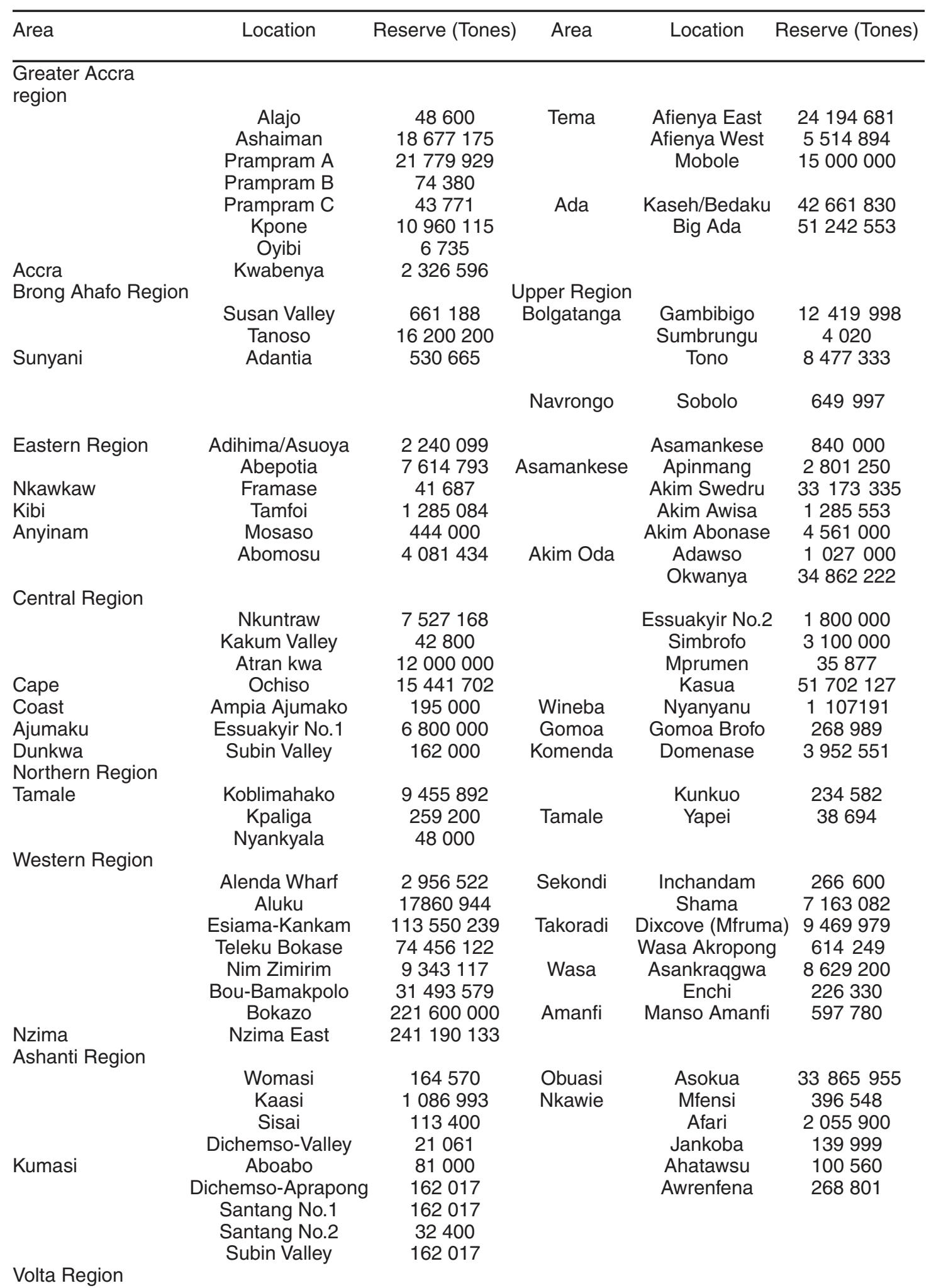




\begin{tabular}{lccccc} 
Ho & Adidome No. 1 & 7755319 & Bowiri & Kalakpa & 501440 \\
Anfoega & Adidome No. 1 & 469800 & & Tuwotsive & 1944 \\
& Tangidome & 7614 & & Amanfro & 200000 \\
& Nuzeme & 10083 & Dayi & Dayi River Basin & 997900 \\
Gbefi- & Toga & 42163 & Katekrachi & Woroto & 7027707 \\
Hoeme & Kpetoe & 29160 & & Adankpe & 2273361 \\
& Avehiboe & 27540 & Hohoe & Aduator & 35554085 \\
& Valexo & 16300 & Kpoglo & & 9413582 \\
Kudzra & Aklamapata & 6318 & Kadjebi & Kadjebi & 97742979 \\
\hline
\end{tabular}

Table 2: Properties of some clay deposits from some regions in $\mathrm{Ghana}^{4}$

\begin{tabular}{cccccc}
\hline Clay/Sample No. & Wet-Dry & Moisture & Plasticity & Water of Plasticity & Colour of \\
Shrinkage (\%) & Content (\%) & (Rule of Thumb) & (By Weight) & Raw Clay
\end{tabular}

\begin{tabular}{|c|c|c|c|c|c|}
\hline \multicolumn{6}{|c|}{$\begin{array}{l}\text { Western Region } \\
\text { Esiama (ESA) }\end{array}$} \\
\hline ESA1 & 2.00 & 10.54 & Low & Low & \\
\hline ESA2 & 3.28 & 21.11 & Medium & High & \\
\hline ESA3 & 4.52 & 25.00 & Medium & High & \\
\hline ESA4 & 2.83 & 16.19 & Medium & High & \\
\hline \multicolumn{6}{|c|}{ Nkroful(NKA) } \\
\hline NKF1A & 4.16 & 19.18 & High & Medium & \\
\hline NKF1B & 1.9 & 6.45 & Low & Low & \\
\hline NKF2A & 3.84 & 17.28 & & & \\
\hline NKF2B & 2.59 & 7.89 & Low & Low & \\
\hline NKF3A & 4.39 & 17.39 & Medium & Medium & \\
\hline NKF3B & 2.32 & 11.9 & Low & Low & \\
\hline \multicolumn{6}{|l|}{ NKF4A } \\
\hline NKF4B & 3.00 & 9.23 & Low & Low & Yellow Ochre \\
\hline \multicolumn{6}{|c|}{ Teleco-Bokazo (TB) } \\
\hline TB1 & 4.13 & 18.91 & Low & High & White \\
\hline TB2 & 2.26 & 25.00 & Low & High & White \\
\hline TB3 & 3.46 & 26.24 & Low & High & White \\
\hline TB4 & 2.51 & 25.21 & Low & High & White \\
\hline \multicolumn{6}{|c|}{ Central Region } \\
\hline \multicolumn{6}{|c|}{ Abonku (AB) } \\
\hline $\mathrm{AB} 1$ & 6.12 & 18.11 & High & High & Brown \\
\hline AB2 & 6.37 & 18.75 & High & High & Light Brown \\
\hline AB3 & 4.68 & 14.28 & High & High & Light Brown \\
\hline \multicolumn{6}{|c|}{ Pomase (PM) } \\
\hline PM1 & 4.56 & 20.00 & Low & High & \\
\hline PM2 & 3.54 & 20.00 & High & Low & Silvery Beige \\
\hline PM3 & 2.92 & 8.11 & High & Low & Silvery Green \\
\hline \multicolumn{6}{|c|}{ Basofi-Ningo (BN) } \\
\hline $\mathrm{BN} 1$ & 4.33 & 13.33 & Low & Medium & Light Mangolia \\
\hline BN2A & 2.14 & 2.4 .0 & Low & Medium & Near White \\
\hline BN2B & 4.16 & 14.62 & High & Medium & Greyish White \\
\hline
\end{tabular}




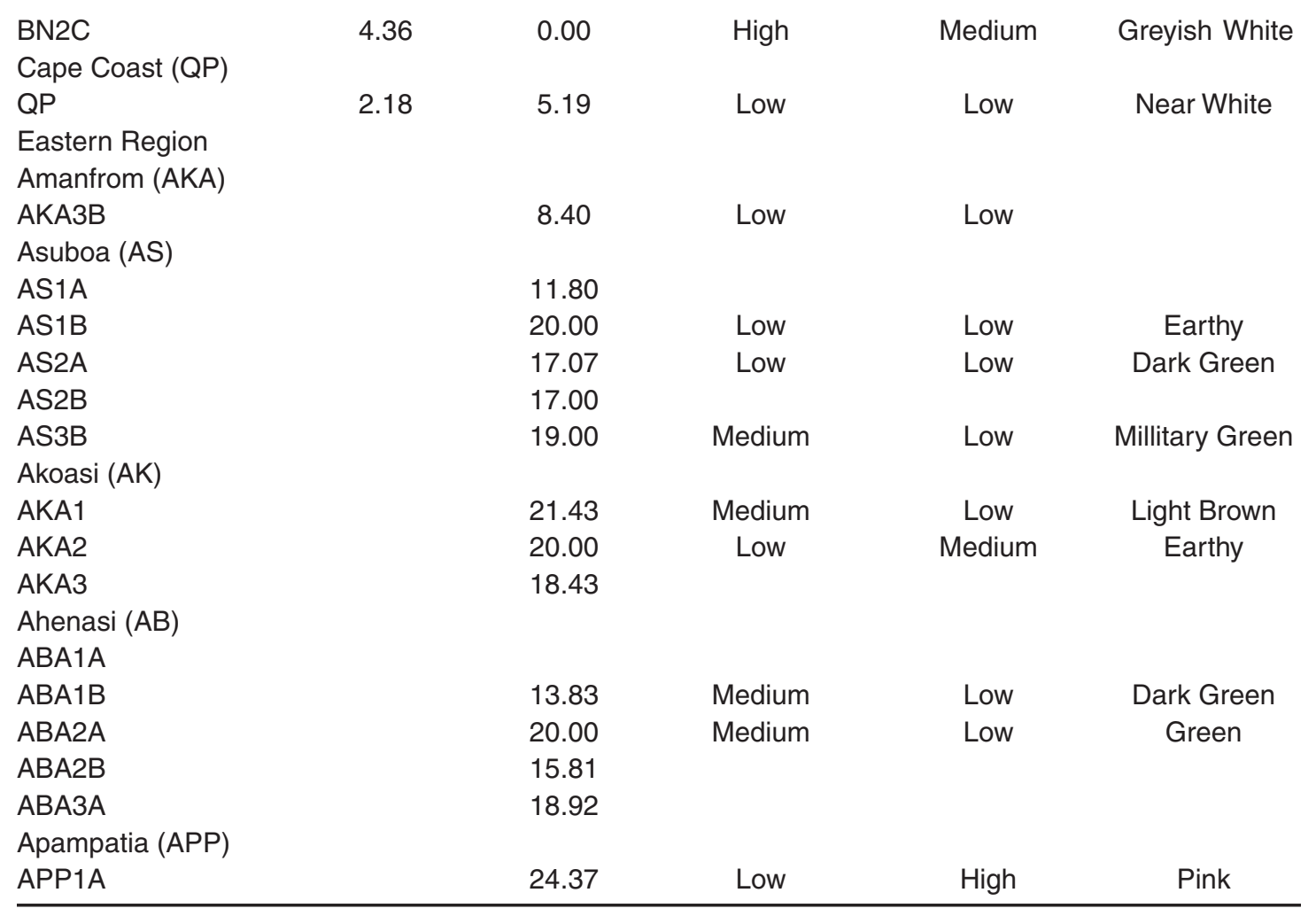

The various deposits consist of different kinds of clay minerals as observed from studies by the Ghana Geological Survey Department-Ceramics Laboratory (1999). ${ }^{4}$ These materials are collected from different location as shown in Table 2. As indicated, they possess different properties such as weight shrinkage, moisture content, plasticity and raw colour.

\section{Properties and Chemical Composition of Some Selected Clay minerals in Ghana}

The clay minerals are basically composed of repeating tetrahedral and octahedral planar sheets. ${ }^{28}$ Tetrahedral sheets have a central silicon ion $\left(\mathrm{Si}^{4+}\right)$ bonded to four oxygen ions $\left(\mathrm{O}^{2-}\right)$ whiles octahedral sheets have a general central ion of aluminium, magnesium or iron bonded to six oxygen ions $\left(\mathrm{O}^{2-}\right)$ or hydroxyl ions $\left(\mathrm{OH}^{-}\right) \cdot{ }^{29}$ The tetrahedral and octahedral sheets form a polymeric aluminosilicate layer which is mostly crystalline in structure. Isomorphous substitution within the sheets of clay leads to different kinds of clay mineral compositions leading to varied properties such as colour, cohesion, ionic exchange, surface area, etc. ${ }^{30}$ Local clay minerals in Ghana also vary among these properties as shown in
Table 2. The variance in properties promotes different applications. ${ }^{31}$

Impurities such as $\mathrm{Fe}_{2} \mathrm{O}_{3}, \mathrm{TiO}_{2}, \mathrm{~K}_{2} \mathrm{O}$ and $\mathrm{Na}_{2} \mathrm{O}$ vary among clay samples from the different localities in Ghana. ${ }^{32,33}$ Colourization of clay is generally due to the presence of certain elements such as $\mathrm{Fe}$ in the clay mineral framework. ${ }^{34}$ For example $\mathrm{Fe}^{2+}$ can convert to $\mathrm{Fe}^{3+}$ through oxidation in the soils and can confer their coloration to the clay material. In addition, the chemical interaction of clay minerals with other organic compounds present in the environment can also influence the colour of the clay materials. ${ }^{35}$ Clay chroma is also dependent on its $\mathrm{pH}$ and increase in $\mathrm{pH}$ due to mineral complexes can increase the overall chroma of the clay materials. ${ }^{36}$ The local clay minerals have plasticity varying from high to low and can infer specific properties leading to the formation of highly expandable and non-expandable clays such as smectites (montmorillonite) and kaolin respectively. Plastic clays such as smectite clays have water surrounding the interlayer cations which causes them to swell in the hydrated form hence, making them highly expandable. Interlayer spaces between sheets increases their surface area comparably and 
also ionic exchange capacity which promotes soil fertility and other applications. ${ }^{37}$ These characteristics have been reported to aid in the substitution of iron mostly within their octahedral sheets. ${ }^{38}$ Non-plastic clays such as kaolin sheets occur in stack and have no interlayer spacing leading to a relatively small surface area, low ionic exchange and low plasticity among others. ${ }^{39}$

A number of plastic clay minerals have previously been reported by the Geological Survey Department of Ghana. ${ }^{4}$ Kaolin is discovered in commercial quantities in most parts of Ghana, including Anfoega, Kibi, Saltpond-Abandze, and Teleku-Bokazo among others. ${ }^{40} \mathrm{~A}$ study conducted on Aferi clay deposits in Tanoso near Kumasi found kaolinite and montmorillonite (smectite groups) clay minerals which are plastic, and exhibit different coloration ${ }^{4}$ Also, similar work conducted by Amoanyi (2012) reported the presence of kaolinite and muscovite in Mfensi Clay deposits in the Ashanti Region. ${ }^{41}$ The chemical analysis of kaolin samples collected from various parts of the country are shown in Table 3. These non-plastic clay minerals are mostly white, light brown, grey and yellow in colour. Minor inclusions of iron in these clays are responsible for the colourization in this materials. ${ }^{42}$ Chemical analysis performed on Aferi and Mfensi as shown in Table 4, revealed additional minerals in their framework indicating their compositional difference due to their location. ${ }^{43}$

Table 3: Chemical Analysis of various Kaolin Samples $^{44}$

\begin{tabular}{lccc}
\hline $\begin{array}{l}\text { Chemical } \\
\text { Composition }\end{array}$ & Kibi & $\begin{array}{l}\text { Saltpond- } \\
\text { Abandze }\end{array}$ & $\begin{array}{c}\text { Teleku- } \\
\text { Bokazo }\end{array}$ \\
\hline $\mathrm{SiO}_{2}$ & 44.72 & 43.7 & 69.3 \\
$\mathrm{Al}_{2} \mathrm{O}_{3}$ & 38.82 & 35.5 & 19.3 \\
$\mathrm{Fe}_{2} \mathrm{O}_{3}$ & 0.12 & 2.4 & 2.3 \\
$\mathrm{FeO}$ & 0.45 & & \\
$\mathrm{CaO}$ & 0.21 & & 0.7 \\
$\mathrm{H}_{2} \mathrm{O}$ & & 16.8 & \\
Loss of ignition & 13.13 & & 6.4 \\
Total & 97.45 & 98.4 & 98.4 \\
\hline
\end{tabular}

Table 4: Major Chemical Composition of some Aferi and Mfensi Clay Samples ${ }^{45}$

\begin{tabular}{lccccc}
\hline $\begin{array}{l}\text { Chemical } \\
\text { Composition } \\
\text { (wt\%) }\end{array}$ & $\begin{array}{c}\text { Aferi } \\
\text { Clay }\end{array}$ & $\begin{array}{c}\text { Aferi } \\
\text { Clay }^{2}\end{array}$ & $\begin{array}{c}\text { Mfensi } \\
\text { Clay }\end{array}$ & $\begin{array}{c}\text { Mfensi } \\
\text { Clay }^{2}\end{array}$ & $\begin{array}{l}\text { Mfensi } \\
\text { Clay }\end{array}$ \\
\hline $\mathrm{Si}_{2} \mathrm{O}$ & 48.88 & 48.9 & 58.56 & 65.6 & 58.6 \\
$\mathrm{Al}_{2} \mathrm{O}_{3}$ & 26.56 & 26.6 & 23.44 & 19.5 & 23.4 \\
$\mathrm{Fe}_{2} \mathrm{O}_{3}$ & 6.66 & 6.7 & 3.63 & 0.8 & 3.63 \\
$\mathrm{CaO}$ & 0.24 & 0.2 & 0.14 & 0.2 & 0.1 \\
$\mathrm{MnO}$ & 0.01 & 0 & 0.02 & 0.2 & 0 \\
$\mathrm{MgO}$ & 1.61 & 1.6 & 1.41 & 0.4 & 1.4 \\
$\mathrm{Na}_{2} \mathrm{O}$ & 1.73 & 1.7 & 2.06 & 0.9 & 2.1 \\
$\mathrm{~K}_{2} \mathrm{O}$ & 0.13 & 0.1 & 1.28 & 0.9 & 1.3 \\
$\mathrm{TiO}_{2}$ & 0.79 & 0.8 & 0.9 & 0.6 & 0.9 \\
$\mathrm{P}_{2} \mathrm{O}_{5}$ & 0.06 & & 0.13 & & \\
$\mathrm{SO}_{3}$ & 0.17 & & 0.18 & & \\
\hline $\mathrm{Ap}_{3}$ & & & & & \\
\hline
\end{tabular}

\section{Applications of Clay in Ghana}

The clay industry in Ghana is focused on processing, fabrication and production of various household gadgets such as porcelains, pots, etc. There is limited research undertaken to understand the physicochemical properties of these clay minerals, as the application of clay materials is influenced by their physical and chemical properties which determine their suitability for specific usage..$^{46}$ Kaolin is mostly cited as an ideal example of nonplastic or non-expandable clay minerals contrary to smectites that are perfectly plastic or expandable. The differences in these clay types are tabulated in Table 5. As shown in Tables 6 and 7, the differences in properties of these clays influence wide ranges of usefulness including biological, ceramics, construction and water purification.

The application of clay materials in Ghana is mostly found in the ceramics industry which is mainly in construction and whitewares manufacturing ${ }^{48}$ In recent times, elevated interest has been shown in the uses of these minerals for environment remediating in Ghana. The biological implications of clay materials are also an area of intense interest due to their geophagy practices amongst Ghanaians especially pregnant women. Research institutes in Ghana are also investigating into the usage of local clay in as an enhanced materialfor various biomedical applications in collaboration with foreign other research institute. The following section provides brief research findings in the aforementioned areas commonly conducted in Ghana. 
Table 5: Comparison between the properties of some clay minerals ${ }^{47}$

\begin{tabular}{lc}
\hline Non-expandable (Kaolin) & Expandable (Smectite) \\
\hline $\begin{array}{lc}\text { 1:1 layer } \\
\text { White or near white } \\
\text { Little or no substitution }\end{array}$ & $\begin{array}{c}\text { Tan, olive, green, white } \\
\text { Minimum layer charge }\end{array}$ \\
Low cation exchange capacity & Tetrahedral and Octahedral substitution \\
Hexagonal flakes & High layer charge \\
Low swelling or cohesion & High cation exchange capacity \\
Low surface area & Thin flakes \\
Very low adsorptive capacity & High swelling or cohesion \\
Low viscousity & High surface capacity \\
\hline
\end{tabular}

Table 6: Industrial applications of kaolin clay minerals ${ }^{47}$

\begin{tabular}{lccc}
\hline Paper coating & Cracking catalyst & Enamels & Bleaching \\
\hline Paper filing & Fiber glass & Pastes and glues & Fertilizers \\
Extender in paint & Cement & Insecticides carriers & Plaster \\
Ceramic raw material & Pencil Leads & Medicines & Filter aids \\
Filler in plastics & Adhesive & Sizing & Cosmetics \\
Filler in rubber & Tanning leather & Textiles & Crayons \\
Extender in ink & Pharmaceuticals & Food additives & Detergents \\
Roofing granules & Linoleum & Polishing compounds & \\
\hline
\end{tabular}

Table 7: Industrial applications of smectite clay minerals ${ }^{47}$

\begin{tabular}{lccc}
\hline Drilling mud & Cat box absorbents & Adhesives & Emulsion stabilizer \\
\hline Foundry bond clay & Beer and wine clarification & Pharmaceuticals & Crayon \\
Pelletizing iron ores & Ceramics & Food additives & Cement \\
Sealants & Pencil leads & De-inking of paper & Desiccants \\
Animal feed bonds & Medical formulations & Tape-joining compounds & Cosmetics \\
Bleach clay & Polishing and clearing agents & Paper & Paint \\
industrial oil absorbents & Detergents & Fillers & Aerogels \\
Agricultural carriers & & & \\
\hline
\end{tabular}

\section{Ceramics}

The characterisation and analysis of clay have influenced the ceramics industry tremendously. Structural clay products which are mostly found in the construction industry are mostly considered heavy clay products. ${ }^{49,50}$ For example, it has been revealed that, the structural integrity of ceramics is influenced by their composition and chemical properties. Further works have also shown that, clay can be molded leading to enhanced cohesive properties with adequate plasticity without undergoing excessive cracking and breakage. ${ }^{51,52}$ It is desirable that clays forming structural products do not contain carbonates since these ions turn to swell leading to crack formation..$^{53}$ Evidence from research findings conducted in Ghana, which then revealed that swelling of clays may cause ceramic products to bloat when fired. ${ }^{54}$ This further agrees with other researchers worldwide indicating that, the properties of clay minerals for ceramic products must be carefully characterized to inform product design. ${ }^{55}$ Based on this it has been realized that better and efficient ceramic products are being produced by using other techniques in order to nullify the swelling effect of mild bloating and shrinkage. ${ }^{56}$ 


\section{Structural Products for Construction: Bricks, Tiles}

The structural products from clay for the construction industry in Ghana are mainly bricks and tiles as shown in Table 5. It is evident that, low plasticity found in kaolin clay minerals are suitable for the production of structural products. ${ }^{57}$ Thus, the Anfoega clay deposits which contains kaolin of commercial quantities are used by the construction industry is due to its suitability. ${ }^{58}$ In the past, the Geological Survey Department of Ghana has also examined the Anfoega, Kibi, and Saltpond clays in which they found to be suitable for the manufacturing of other additional products such as roofing tiles and facing tiles. Structural products are mainly popular with non-plastic clays which is commonly kaolin based. However, plastic clays in the right proportions with non-clay materials have been successful for the production of bricks. Bauxite, red mud and plastic clay from Ghanaian communities of Awaso and Tetegbu respectfully formed a composites to produce bricks of optimal mechanical strength. ${ }^{59}$ The properties of clay minerals for structural products are tolerable among Ghanaian clays. Composite formulations may also improve clay suitability for structural products. ${ }^{60}$

\section{Concrete}

The Council for Scientific and Industrial Research (CSIR) Ghana has investigated into the use of pozzolans (aluminosilicate materials) which are readily available in most regions (Awasso and Anfoega) of the country as binder for the production of cement. CSIR findings indicated that, Pozzolans acquire cementious properties when they react with calcium hydroxide $(\mathrm{CaOH})_{2}$ in the presence of water. It was also indicated that the overall strength of concrete material is enhanced by pozzolana clay modifications. ${ }^{61,62}$ Pozzolana clays have fine homogeneous particle sizes which allows denser packing for water tightness and has therefore the potential to replace portions of Ordinary Portland Cement (OPC) in concretes. ${ }^{63}$ Research has revealed that, to obtain optimal strength in concrete materials, a $25 \%$ pozzolana clay with respect to the bulk material may be added as a binder. ${ }^{64} \mathrm{~A}$ comparative study of pozzolan with OPC shows that, improvements in strength was achieved by a combination of pozzolan with OPC, see Fig. 2.65

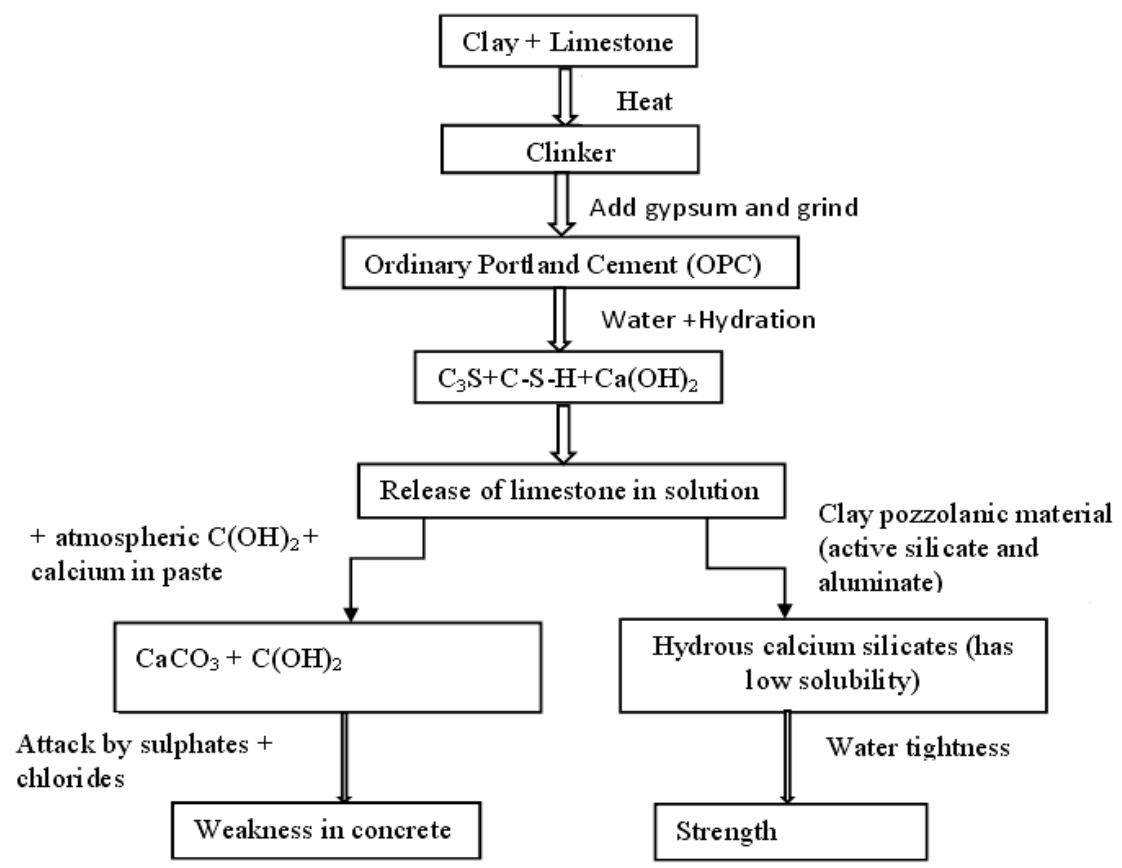

Fig. 2. A schematic of the reaction between pozzolana clay and cement

\section{Whitewares}

These are ceramics that are mostly used for domestic applications including the manufacturing of products such as dinner ware, sanitary ware, floor and wall tiles, pottery, spark plugs, electrical porcelain, chemical and refractory porcelain among others. ${ }^{66}$ Furthermore, a combination of non-clay materials and others impurities such as quartz and 
feldspar, clay minerals are versatile for the whiteware industry. The production of electric porcelain and other ceramics to replace environmentally non-friendly foreign ones have been investigated to be technically viable using Ghanaian local clay minerals. $^{5}$

\section{Environmental Remediation and Protection}

The remediation and protective effects of clay minerals have shown detoxifying characteristics on heavy metals and other organic contaminants, as well as enriching the nutrient qualities of the soil. ${ }^{67}$ The ideal features of clay including high permeability, cation exchange capability, catalysis, adsorption, large surface area and swelling ability of clay minerals makes them useful for protecting and reclaiming important environmental resources such as water and land. ${ }^{68}$

\section{Water Purification}

Clay minerals have high cation exchange capability and therefore their composites can contribute to water safety through their ability to remove metals, organic and inorganic contaminants. ${ }^{69}$ The presence of heavy metal ions ( $\mathrm{As}, \mathrm{Pb}, \mathrm{Zn}$ ) and organic compounds are the general causes of water pollution which makes water unsuitable for domestic usage. ${ }^{70}$ Other works in this area seeks to develop clay catalytic materials that can filter and degrade most of the contaminant organic compounds. For example, the combination of clay and lime removed about $70 \%$ of dye that decolourizes water. ${ }^{71}$ The adsorptive properties of clay are very important for the removal of heavy metals and this has been demonstrated using Na-montmorillonite intercalated with dodecylamine. ${ }^{72}$ The rate of adsorption of metal ions by clay minerals is inversely proportional to the surface area of the clay material and can enhance the electrostatic attraction between aluminosilicate clay mineral surface and the metal ions contributing to the adsorption properties of these clays. ${ }^{73,74}$ Such mechanism has been used in hard water purification which is due to the presence of polyvalent metals, $\mathrm{Ca}^{2+}$ and $\mathrm{Mg}^{2+} .{ }^{75}$

\section{Soil Fertility}

Most soil infertility result from the transfer of chemical species. ${ }^{76}$ The problem normally arises from the inability of receptors to absorb transferred chemical species. Soils can be remediated for agricultural use by the effective transfer and reception of cations $\left(\mathrm{K}^{+}, \mathrm{Na}^{+}, \mathrm{Ca}^{2+}, \mathrm{Zn}^{2+}, \mathrm{Fe}^{2+}, \mathrm{Mn}^{2+}\right.$, $\mathrm{NH}^{4+}$ etc.) and anions $\left(\mathrm{NO}_{3}^{-}, \mathrm{PO}_{4}^{3-}, \mathrm{HCO}_{3}^{-}, \mathrm{SO}_{4}{ }^{2-}\right.$, $\mathrm{SO}_{3}^{-}$, etc.) to the appropriate surface. ${ }^{77}$ The ability of a clay material to remediate the soil depends on the ionic exchange capability of the clay mineral (Fig. 3). In other words, the greater the ionic exchange capability of the clay mineral, the higher its ability to remediate the soil through transfer of chemical species. ${ }^{78}$ Their exchange capabilities differ among clay mineral forms. The rate of adsorption also depends on the desired application. Clay mineral deposits in Ghana are formed by weathering, erosion and sedimentation. ${ }^{3}$ These clays have essential cations for exchange. ${ }^{79}$ In the design of soil fertilizers, cations and anions are formulated for the exchange. ${ }^{80}$ Clay minerals such as bentonite of the smectite group have charged surface for suitable ionic exchange.$^{81}$ Colloidal clay minerals in soil have high impermeability, viscosity and elasticity. ${ }^{82}$ The impermeability of clay prevents swelling of fertilizers which promotes their equitable use in fertilizing the soil for farming. ${ }^{83}$ It also increases soil fertility by promoting aeration, controls heat exchange and soil temperature. Expandable clays such as smectites increases drying to which in turn increase soil $\mathrm{pH}$ to the benefit of growing plants in the soil. ${ }^{84}$ Soil environmental remediation can be achieved by clay materials with high electrostatic surface. ${ }^{85}$ The adsorptive and crack resistant nature of clay materials is important for remediating waste lands. ${ }^{86}$ Aferi and Mfensi clays in Ghana are plastic and anti-leakage. Plastic and anti-leakage soils are utilized for landfills. These local clays in Ghana are suitable for reclaiming waste lands as well. ${ }^{87}$

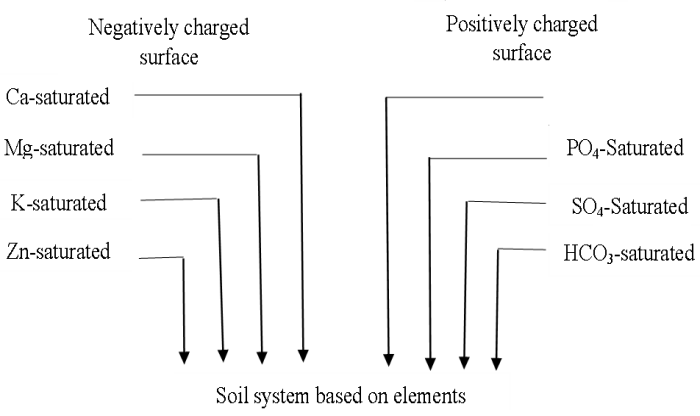

Fig. 3. Soil additive elements in exchangeable form ${ }^{88}$

\section{Nuclear Waste Disposal}

Radioactive materials possess harmful health risks due to their chemical toxicity. High-levels of radioactive materials are disposed from nuclear reactors. ${ }^{89}$ The active radionuclei 
are disposed as waste in metal containers buried deep underground. ${ }^{90} \mathrm{~A}$ multi-barrier compartment system is proposed as a better alternative over the current single barrier system. Multi-barrier systems provides assured security of containment and prevents possible leakage into drains. ${ }^{91}$ Clays such as smectites have high adsorptive potentials that enables it bind with other materials against leach have proven water impermeability and high swelling capability to act as sealants..$^{92} \mathrm{~A}$ multi-barrier system composed of clay and metals (canisters) would therefore be advantageous to effectively contain high-levels radioactive waste materials. ${ }^{93}$ Clay natural materials and artificially engineered metals confines harmful radioactive waste for years to protect the biosphere. Clay-cement composite provides durable mechanical strength to immobilize radioactive waste. ${ }^{94} \mathrm{~A}$ mixture of cement with clay compared with cement and other materials have comparably reliable sorption competence to prevent leachability of radioactive waste. ${ }^{95}$ Long-term storage and disposal of radioactive waste could involve rather aggressive processes. Immobilization is critical to the safe storage or disposal of radioactive waste. ${ }^{96}$

\section{Healthcare Applications}

Clay materials used in drugs and other health benefits are processed natural clays. ${ }^{97}$ Natural clay treatment improves the chemical and physical properties such as single ionic charge carrier and fine particle size which enhances their property for a particular use ${ }^{98}$ Chemical and structural features are prime factors influencing the use of clay in pharmaceutical, cosmetic, food packaging and other health applications. ${ }^{99}$ The ideal characteristics of clay for health uses is hampered by the presence of impurities. ${ }^{100}$ Some components of the interlayer elements and certain ionic attachments to the surface may be biologically unfriendly. The inclusions of elements such as arsenide, zirconium, mercury, lead, lithium, cobalt, copper, nickel, molybdenum, vanadium, etc. in the clay minerals are potentially toxic to biological systems. ${ }^{101}$ The medical properties of clay minerals have been known by Ghanaians for centuries. They are especially consumed by geophagic people and especially pregnant women. The mineral component of clay such as iron, calcium, and zinc, improves health. However, these clays are mostly unprocessed hence contains potentially toxic contaminants such as $\mathrm{Pb}, \mathrm{As}, \mathrm{Hg}, \mathrm{Cd}$, etc. ${ }^{102}$
These toxic elements unknowingly affect individual's health. The health applications of clay minerals may encompass biomedical applications, and food packaging. ${ }^{103}$

\section{Biomedical Applications}

Pharmacokinetics (design and the production of medicinal consumables and medical devices) and cosmetics are classes of biomedical applications. Clay materials have desirable surface area and adsorptive qualities. These materials also have negligible toxicity, are biocompatible which means they can be used in most pharmaceutical, cosmetic products and in drug delivery applications. ${ }^{104-105}$, The clay materials also have antibacterial, antiinflammatory and antiseptic properties, etc. ${ }^{106}$ These are included in medical drugs for purposes such as treatment of diarrhoea, gastrointestinal and other medical conditions. ${ }^{107}$ The right administration of bentonite (type of smectite clay) is reported to treat cases such as itching, chicken pox, etc. and for enhancing healing drug delivery. Bentonite is also used in wound healing for soothing wounds, cuts and bruises as well as for muscle damage. ${ }^{108}$ Clay materials have also found applications in cosmetic products. They are used in the stabilization of oil-in-water emulsions. ${ }^{109-110}$ These are also used against perspiration and for covering blemishes. It gives opacity to the skin against sun radiations and to remove toxins from skin pores. ${ }^{111}$ Clays in combination with polymers improve the strength of hydrogels. ${ }^{112}$ Hydrogels have applications for delivering drugs and in tissue engineering to grow new cells, tissues and some cartilages. ${ }^{113}$ Tiburu et al., ${ }^{15}$, used clay minerals from the Northern Region of Ghana for the enhancement of bone growth in vitro. Alternatively, bone growth could be inhibited by clay minerals. ${ }^{101}$ Clay materials have high ionic exchange capability. ${ }^{114}$ The ionic exchange capability of clays is used in drug delivery to carry appropriate ionic drugs. Drugs are loaded through various means of bonding and attachments onto the surface of the clay particles. ${ }^{116}$ The hollow nature of tubular clays such as allophanes, imogolites and halloysites are also used for drug delivery purposes. ${ }^{117}$ The drugs are accepted by corresponding ions or charged surfaces present in the biological system. Ionic exchange is the predominant means for drugs to interact with clay minerals particles. ${ }^{118}$ The claydrug ion exchange is possible when clay mineral 
particle has a permanent charge or a charge controlled by $\mathrm{pH} .{ }^{119-120}$ Clay minerals such as smectites and vermiculites have a charge of cation. They normally interact with amines or heterocyclic functional groups. ${ }^{121}$ Allophanes, imogolites and aluminium oxides have $\mathrm{pH}$ dependent charges. These commonly interact with carboxylates. ${ }^{122}$ High molecular weight drugs are normally unionized hence bonded by adsorption. ${ }^{123}$ Chymotrypsin drug formed interaction with montmorillonite clay mineral particles through adsorption by electrostatic forces. ${ }^{124}$ Clays with neutral charges form hydrophobic associations with drugs through hydrogen bonding and Van der Waals forces of interaction. ${ }^{125}$ The surface of clay minerals successfully bonds to DNA and RNA by hydrogen bonding. ${ }^{126}$ Drug concentration, $\mathrm{pH}$, temperature, electrolyte concentration, valence charge and dielectric constant are factors which determine the assembly of drugs onto clay mineral particle surfaces. ${ }^{127}$

\section{Food Packaging and Storage}

Wines are expected to be free from suspended matter. They appear dull and non-transparent even if their smell and flavour remains. ${ }^{128}$ Clarification is done in wine tasting to remove visible particles in the liquid wine. Clarification may be defined as the separation of insoluble substances such as dead fungi, yeast, protein, cells, and bacteria. The process which precedes bottling may be through fining, filtration, pasteurization, and centrifugation. ${ }^{129}$ Clay minerals are utilized for the clarification of wine such as white wine. Bentonite clay is used as a fining agent for the agglomeration and settling of colloids in wines. Clarification by clay agents is used both in alcoholic and non-alcoholic beverages. The clarification capability of clay is enabled by its adsorptive property. Suspended materials in wine therefore bind to the surface of bentonite to achieve clarification. ${ }^{130}$ The bleaching process of most edible oils is done to improve its appearance and performance. During bleaching, impurities are removed to improve the high quality standard of oil for consumption. Bleaching of oil is done to decolour, reduce chlorophyll content, remove residual soap and gum, remove trace metals and oxidation products. ${ }^{131}$ The bleaching process is achieved by the mixing of oil and adsorbent bentonite clay followed by filtration. The conversion of carboxylic acid to esters in the presence of alcohol and acid catalyst defines esterification reactions. ${ }^{132}$ Esters are characterized by their characteristic odour hence normally used as synthetic flavours, cosmetics, etc. The acid treatment of clay gives excellent catalytic properties in esterification reactions. The esterification of fatty-acids was enabled by acid-activated natural smectite clay as catalyst. ${ }^{133}$ The global fruit and vegetable industry store their products using refrigerators or storage rooms. Whiles the former consumes much electric power, the later mostly as a result of excessive heat leads to the spoilage of food causing significant loss of income and revenue. New research has highlighted the potentials of clay as an alternative. A low cost technology and eco-friendly bentonite clay pyramid provides an efficient storage of the food. The technology which can be a preferred alternative preserves physiological weight and organoleptic qualities. ${ }^{134}$

\section{Clothing and Paints}

Textiles are expected to improve in the quality of material and dye-ability. The fabric industries are required to enhance clothing characteristics such as susceptibility to flame and thermal degradation. Textiles coated with thin layer of nanoclay as compared to raw textiles have improved characteristics. In addition, textiles coated nanoclay of bentonite, acid and electrolyte admixtures improve dye-ability. Nanoclay interacts with both direct and basic dye through favourable ion exchange and hydrogen bonding. Nanoclay increases water content. ${ }^{135}$ This enables the quality of paint through increased diffusion of dye colour. Clays are found to increase the stability efficiency of paints which are basically oil emulsions. ${ }^{136}$ Clays in emulsions which is due to their adsorptive character, absorbs water to prevent water penetration into paint which could degrade paint. ${ }^{137}$

\section{Detergents}

The qualities of a preferred detergent are emulsifying ability and suspension of fats. ${ }^{138}$ Metallic earth ions such as $\mathrm{Ca}^{2+}$ and $\mathrm{Mg}^{2+}$, hinders the electrical abilities of detergents and entry into fabrics. The ion exchange of clay causes clay to bind to metal ions and improve the washing capability of detergents. ${ }^{135}$ Clay properties such as large surface area, ion exchange and adsorption results in important qualities of lather and light 
foam, dissolution of detergent for fibre penetration, adsorption of impurities from fibre, softening of hard water by ion exchange, agglomeration of fats resulting in their suspension from foam when clay is used in detergents. ${ }^{136}$

\section{Energy}

Global energy is in constant shortfall and is insufficient. New methods continue to be explored for a more sustainable alternative to meet rising demands. Cooling and heating loads for residential purposes account for a considerable proportion of general energy consumption. ${ }^{139}$ Phase change materials such as hydrated salt, fatty acids and paraffin in combination with adsorptive materials such as bentonite can store heat in latent form. Such composite has a good heat transfer rate to increase heat per unit volume relative to structures of unlike materials. Electrical carriers require good insulation. Clay has been studied to provide good insulation to electrical carriers. ${ }^{5,41,43,138}$ Electrical groundings have approximately $0 \mathrm{~V}$. Clay materials have been investigated to improve electrical grounding. A mixture of clay minerals with $\mathrm{Na}_{2} \mathrm{CO}_{3}, \mathrm{MgSO}_{4}$, $\mathrm{MgCO}_{3}, \mathrm{Na}_{2} \mathrm{CO}_{3}$ are expected to improve electrical grounding. ${ }^{139}$

\section{CONCLUSION}

This review highlights some of the research undertakings in the field of clays ceramics in Ghana and the important applications derived from these materials research. The synthesis and processing of clays have also be highlighted in the text.

The potential applications are directly linked to the understanding of the materials properties of local clay deposits base on this review, the usefulness of clay deposits in Ghana ranges from the development of pozzolans for structural products such as bricks and tiles, to environmental remediation and other products such as electrical insulators. The applications of clay also extends to other economically viable areas sincluding pottery and construction industry.

In order to derive the full potentials of the economic gains of clay minerals in Ghana, the following two recommendations are proposed

- $\quad$ Pursue in-depth research into the potential utility of the various clay deposits in areas such as medical applications, water remediation, energy storage and food packaging

\section{ACKNOWLEDGEMENT}

A. Yaya acknowledges support from the Carnergie BANGA-Africa Project, University of Ghana for funding this study.

\section{REFERENCES}

1. Albarelli, J. Q.; Santos, D. T.; Cocero, M. J; Meireles, M. A. A. Materials., 2016, 9(6), 494.

2. Downes, D. R.; Colum, J.; Envtl, L. Minnesota Intellectual Property Review., 2000, 25, 253-282.

3. Kesse, G. O.; Balkema, A. A. Journal of Water Resource and Protection., 1985, 1(3), 522-530.

4. Ghana Geological Survey Dept. Ghana Geological Survey., 1999, 1, 11-15.

5. Dowuona, A. N. N.; Yaya, A.; Nyankson, E.; Efavi, J. K.; Damoah, L. N.W; Dodoo-Arhin, D.; Apalangya, V.; Annan, E.; Tiburu, E.K.; OnwonaAgyeman, B.; Tomiczek, B. Jour. of Ceramic Processing Research., 2018, 19, 95-100.

6. Bradl, H. Academic Press., 2005, 6(1), 68-89.

7. Hillel, D. Academic press., 2003, 1, 56-90.

8. Murthy, V.N. CRC Press., 2002, 1, 10-25.

9. Hounslow, A. CRC Press, 1995. 1, 107-112.

10. Dondi, M.; Raimondo, M.; Zanelli, C. Applied
Clay Science., 2014, 96, 91-109.

11. Bertolino, S. R.; Gastaldi, M. R.; Zimmermann, U.; Laguens, A. Applied Clay Science., 2016, 131, 158-174.

12. Tiburu, E. K.; Salifu, A. A.; Aidoo, E. O.; Fleischer, H. N. A.; Manu, G.; Yaya, A.; Zhou, H.; Efavi, J. K. Journal of Nano Research., 2017, 48, 156-170,

13. Efavi, J.K.; Tiburu, E. K.; Yaya, A.; Damptey, L.A.; Bowen-Dodoo, E.; Asimeng, B.; Zhuang, J. Jour. of Ceramic Processing Research., 2016, 17(10), 1068-1073.

14. Efavi, J.K.; Yaya, A.; Adeborna, S.; Fobil, J. Advanced Materials Research., 2014, 10, 936.

15. Tiburu, E.K.; Fleischer, H.N.; Aidoo, E.O.; Salifu, A.A.; Asimeng, B.O. Journal of Biomimetics, Biomaterials and Biomedical Engineering., 2016, 28, 66-77. 
16. Uddin, M. K. Chemical Engineering Journal., 2017, 308, 438-462.

17. Chatel, G.; Novikova, L.; Petit, S. Applied Clay Science., 2016, 119, 193-201.

18. Ghana Geological Survey Dept. Ghana Geological Survey, 2009, 1, 14-17.

19. Uddin F. Metallurgical and Materials Transactions., 2008, 39(12), 2804-2814.

20. Komadel, P. Applied Clay Science., 2016, 1, 84-99.

21. Cheng, H.; Liu, Q.; Yang, J.; Du, X.; Frost, R.L. Applied Clay Science., 2010, 50(4), 476-80.

22. Tonle, I.K.; Diaco, T.; Ngameni, E.; Detellier, C. Chemistry of Materials., 2007, 19(26), 6629-36.

23. Davis, M.E. Nature., 2002, 417(6891), 813-821.

24. Singla, P.; Mehta, R.; Upadhyay, S. N. Green and Sustainable Chemistry., 2012, 2(1) 21-25.

25. Goudie A.S; Middleton N. J. Earth-Science Reviews., 2001, 56, 179-204.

26. Ngulube, T.; Ray, J.; Masindi, V; Maity, A. Journal of Environmental Management., 2017, 191, 35-57.

27. Michalkova, A.; Martinez, J.; Zhikol, O.A.; Gorb, L.; Shishkin, O.V.; Leszczynska, D. Journal of Physical Chemistry., 2006, 110(42), 21175-21183.

28. Pavlidou, S.; Papaspyrides, C.D. Progress in polymer science., 2008, 33(12), 1119-98.

29. Lu, S.; Sun, F.F.; Zong, Y.T. Catena., 2014, 114, 37-44.

30. Christie, A.B.; Thompson, B.; Brathwaite, B. New Zealand Mining., 2000, 27, 26-43.

31. Andrews, A.; Gawu, S.K.Y.; Appiah, M.; Indome, A.; Fudzi, A. A. J. Springer Science., 2014, 55(2), 143 - 147.

32. Al-Juboury, A. I. Acta Geologica Polonica., 2009, 59(2), 269-282.

33. Churchman, G. J.; Gates, W. P.; Theng, B. K. G.; Yuang, G. Development in Clay Science., 2006, 1, 625-675.

34. MacEwan, D. M.; Wilson, M. J. Soil Science Society of America., 1980, 5, 197-248.

35. Smith, T. Durham University, 1978, 1, 56-78.

36. Cornell, R.M.; Schwertmann, U. John Wiley \& Sons., 2003, 13, 139-148.

37. Ryan, W. Pergamon Press., 2013, 2, 799-814.

38. Tagbor, T, A.; Boakye, K. A.; Sarfo-Ansah, J.; Atiemo, E. Int. Journal of Engineering Research and Applications., 2015, 5(8), 28-33.

39. Amoanyni, R.; Kwawukume, P. S.; Francis,
M. Y. International Journal of Engineering Research in Africa., 2012, 8(1), 1 -15.

40. Gillson, J. L.; Economic Geology., 1960, 55(4), 629-44.

41. Yaya, A.; Knowles K. M. Research Horizons., 2017, 32, 30-31.

42. Ghana Geological Survey Dept. Ghana Geological Survey., 2006, 1, 12-15.

43. Yaya A.; Tiburu, E. K.; Vickers, M. E.;, Efavi, J. K.; Onwona-Agyeman, B.; Knowles, K. M. Applied Clay Science., 2017, 150, 125-130.

44. Crini, G. Bioresource technology., 2006, 97(9), 1061-85.

45. Murray, H. H. Clay minerals., 1999, 34(1), 39-39.

46. King, J. R. Woodhead publishing-Elsevier., 2001, 1, 5-9.

47. Dondi, M. Applied Clay Science., 1999, 15, 337-366.

48. Semiz, B. Applied Clay Science., 2017, 137, 83-93.

49. Hui, C.; Zhi, L.; Qin, A.; Hu, T.; Ping, H. Applied Clay Science., 2016, 119, 3-7.

50. Iskender, E. Measurement., 2016, 93, 359-371.

51. Vrolijk, P. J.; Urai, J.L.; Kettermann, M. Journal of Structural Geology., 2016, 86, 95-152.

52. Kwame, J.; Damoah, L.; Yaw, D.; Dodoo, D.; Tetteh, D. Applied Clay Science., 2012, 65(66), 31-36.

53. Dordio, A. V.; Miranda, S.; Ramalho, J. P. Journal of Hazardous Materials., 2017, 323, 575-583.

54. Carretero, M.I.; Pozo, M. Applied Clay Science., 2010, 47, 171-181.

55. Lyons, S.C. Engineering Corporation, United States patent., 1978, 4, 125-411.

56. Tano-Debrah, K.;Bruce-Baiden, G. Nature Science Report and Opinion., 2010, 2(6), 77-81.

57. Konadu, D. S.; Annan, E.; Buabeng, F. P.; Yaya, A. American Journal of Materials Science., 2013, 3(5), 110-119.

58. Abo, O.; Fan, M.; Feo, L.; Hui, D. Composites Part B., 2016, 98, 314-329.

59. Bediako, M.; Gawu, S.K.; Adjaottor, A.A. Construction and Building Materials., 2012, 29, 667-71.

60. Bediako, M.; Atiemo E. Journal of scientific research \& reports., 2014, 3(23), 3018-3030.

61. Brandt, A.M. CRC Press., 2017, 2, 8-15.

62. Amankwah, E. O.; Bediako, M.; Kankam, C. K. International Journal of Materials Science and Applications., 2014, 3(3), 410-419.

63. Sabir, B.B.; Wild, S.; Bai, J. Cement and Concrete Composites., 2001, 23(6), 441-54. 
64. O'Bannon, L. Dictionary of ceramic science and engineering: Springer Science., 1984, 3, 56-79.

65. Wuana, R.A.; Okieimen, F.E. Ecology ISRN., 2011, 59, 58-66.

66. Lin, J.; Chan, Y.; Lan, Y. MDPI Materials., 2010, 3(4), 2588-2605.

67. Yaya, A.; Agyei-Tuffour, B.; Dodoo-Arhin, D.; Annan, E.; Nyankson, E.; Konadu, D. S.; Sinabobye, E.; Baryeh, E. A.; Ewels, C. P. Global Journal of Engineering, Design and Technology., 2014, 1(2), 32-41.

68. Förstner, U.; Wittmann, G.T. Springer Science \& Business Media., 2012, 62, 109-115.

69. Donald, I.W. John Wiley \& Sons., 2010, 1, 337-357.

70. Nicotera, I.; Enotiadis, A.; Angjeli. K.; Coppola. L.; Ranieri, G.A.; Gournis, D. Journal of Physical Chemistry., 2011, 115(29), 9087-97.

71. Theng, B.K.; 2012, Elsevier., 2012, 2, 117-129.

72. Krishna, A. S.; Ramachandran, R.; Kalidhasan, S.; Rajesh, V.; Rajesh, N. Chemical Engineering Journal., 2012, 57, 396-405.

73. Pashley, R.M.; Israelachvili, J.N. Journal of Colloid and Interface Science., 1984, 97(2), 446-55.

74. Post, W.M.; Kwon, K.C. Global change biology., 2000, 6(3), 317-27.

75. Scherr, S. J.; Satya, Y. I. F. Intl Food Policy Res Inst., 1995, 1, 33-37.

76. Liang, B.; Lehmann, J.; Solomon D.; Kinyangi, J.; Grossman, J.; O'neill, B.; Skjemstad, J.O.; Thies, J.; Luizao, F.J.; Petersen, J.; Neves, E.G. Soil Science Society of America Journal., 2006, 70(5), 1719-30.

77. Doe, E. D.; Awua, A.; Achoribo, S.E.A.; Donko, S.; Baidoo, I.; Opata, N.S.; Ampong, A.G. Elixir Appl. Biology., 2012, 47, 8633-8636.

78. Barber, S.A. John Wiley \& Sons., 1995, 1, 78-89.

79. Gillman, G.P. Applied Clay Science., 2011, 53(3), 361-365.

80. Craig, R.F. Soil mechanics, Springer., 2013, 7, 1-5.

81. De Boodt, M.F. Springer US., 1990, 214, 517-556.

82. Biswas, T.D.; Mukherjee, S.K. Tata McGrawHill Education., 2001, 1, 77-85.

83. Kar, P.; Mishra, B.G. Biochemical Pharmacology., 2016, 1, 1962-1969.

84. Sparks, D.L. Academic press., 2003, 2, 78-79.

85. Sarfo-Ansah, J. Doctoral dissertation, Kwame Nkrumah University of Science and Technology, Kumasi., 2010, 1, 23-34.
86. Slovic, P.; Layman, M.; Flynn, J.H. Science and Policy for Sustainable Development., 1991, 33(3), 6-30.

87. Chapman, N.; Hooper, A. Proceedings of the Geologists' Association., 2012, 123(1), 46-63.

88. Biedscheid, J. A. Water Environment Research., 2001, 72(6), 1283-339.

89. Ismadji, S.; Soetaredjo, F.E.; Ayucitra, A. Springer., 2015, 325, 74-83.

90. Selli, P.; Leupin, O.X. Clays and Clay Minerals., 2013, 61(6), 477-98.

91. Pearlman, L. US Environmental Protection Agency., 1999, 1, 1-61.

92. Pusch, R.; Yong, R.N. CRC Press., 2006, 76, 1-38.

93. Ewing, R.C.; Weber, W.J.; Lian, J. Journal of Applied Physics., 2004, 95(11), 5949-71.

94. López-Galindo, A.; Viseras, C.; Cerezo, P. Applied Clay Science., 2007, 36(1), 51-63.

95. Droy-lefaix, M.T.; Tateo, F. Applied clay science., 2000, 17(5), 207-21.

96. Kiliaris, P.; Papaspyrides, C.D. Progress in Polymer Science., 2010, 35(7), 902-958.

97. Pais, I.; Jones, Jr. J.B. The handbook of trace elements. CRC Press, 1997, 1, 1-24.

98. Abebe, Y.; Bogale, A.; Hambidge, K.M.; Stoecker, B.J.; Bailey, K.; Gibson, R.S. Journal of Food Composition and Analysis., 2007, 20(3), 161-8.

99. Emamifar, A. Advances in nanocomposite technology., 2011, 1, 12-15.

100. Aguzzi, C.; Sandri, G.; Cerezo, P.; Carazo, E.; Viseras, C. Clay Minerals., 2016, 7(10), 22-36.

101. Tiburu, E.K.; Kankpeyeng, B.W.; Nkumbaan, S.N.; Salifu, A.A; Zhuang, A. Journal of Biomimetics, Biomaterials and Biomedical Engineering., 2017, 30, 45-60.

102. Choy, J.H.; Choi, S.J.; Oh, J.M.; Park, T. Applied Clay Science., 2007, 36(1), 22-32.

103. Asantewah, M.; Korankye, M.; Darko, G.; Dodd, M. Toxicology Reports., 2016, 134, 644-651.

104. Hauser, R.L. United States patent US 9., 2015, 011, 934,

105. López-Galindo A.; Viseras C.; Cerezo P. Applied Clay Science., 2007, 36(1), 51-63.

106. Zhou, D.; Abdel-Fattah, A.; Keller, A.A. Environmental science \& technology., 2012, 46(14), 7520-6.

107. Viseras, C.; Aguzzi, C.; Cerezo, P.; LopezGalindo A. Applied Clay Science., 2007, 36(1), 37-50. 
108. Zeng, QH.; Yu, A.B.; Lu, G.Q.; Paul, D.R. Journal of nanoscience and nanotechnology., 2005, 5(10), 1574-92.

109. Tanaka, Y.; Gong, J.P.; Osada, Y. Progress in Polymer Science., 2005, 30(1), 1-9.

110. Bailey, S.E.; Olin, T.J.; Bricka, R.M.; Adrian, D.D. Water research., 1999, 33(11), 2469-79.

111. Iliescu, R.I.; Andronescu, E.; Voicu, G.; Ficai, A.; Covaliu, Cl. Applied Clay Science., 2011, 52(1), 62-68.

112. Szczepanik, B. Applied Clay Science., 2017, 141, 227-239.

113. Nowara, A.; Burhenne, J.; Spiteller, M. Journal of Agricultural and Food Chemistry., 1997, 45(4), 1459-63.

114. Mok, S.; Tiwari, D. Applied Clay Science., 2012, 59(60), 84-102.

115. Bergaya, F.; Lagaly, G. Developments in clay science., 2006, 1, 1-8.

116. Suresh R; Borkar S.N; Sawant V.A; Shende V.S; Dimble S.K. International Journal of Pharmaceutical Sciences and Nanotechnology., 2010, 3(2), 901-905.

117. Hanudin, E.; Matsue, N.; Henmi, T. Clay Science., 1999, 11(1), 57-72.

118. Appasaheb, P.S.; Manohar, S.D.; Bhanudas, S.R.; Anjaneri, N. Journal of Advanced Pharmacy Education \& Research., 2013, 3(4). 108-189.

119. Osmond, G.; North, P.; Zealand, N. Clays \& Clay Minerals For Pollution Control., 2006, 1(5), 625-675.

120. Yu, W.H.; Li, N.; Tong, D.S.; Zhou, C.H.; Lin, C.X.; Xu, C.Y. Applied Clay Science., 2013, 80, 443-52.

121. Mignon, P.; Ugliengo, P.; Sodupe, M. Journal of Physical Chemistry C., 2009, 113(31), 13741-9.

122. Sandri, G.; Bonferoni, M. C.; Rossi, S.; Ferrari, F.; Aguzzi, C.; Viseras, C.; Caramella, C. Biomaterials., 2016, 2, 1545-1554.

123. Singleton, V.L.; Sieberhagen, H.A.; De Wet, P.; Van Wyk, C. J. American Journal of Enology and Viticulture., 1975, 26(2), 62-69.

124. Peynaud, E.; Blouin, J. John Wiley \& Sons., 1996, 1, 56-57.

125. Nyankson E.; Annan E.; Agyei-Tuffour B.; Bensah Y.D; Konadu D.S.; Yaya A.; OnwonaAgyeman B.; 2018, Accepted Manuscript, Cogent Engineering, https://doi.org/10.1080 /23311916.2018.1476017

126. Butzke, C. Woodhead Publishing; Purdue University, 2010, Retrieved at: www.extention. purdue.edu/extmedia/fs/fs--w.pdf

127. Vermeiren, W.; Bouvart, F.; Dubut, N. United States patent US., 2014, 8, 624, 071.

128. Bender, M.L. Chemical Reviews., 1960, 60(1), 53-113.

129. Zatta, L.; Ramos, L.P.; Wypych, F. Applied Clay Science., 2013, 80, 36-44.

130. Al-Arfaj, A.A.; Murugan, A.M.; Chinnathambi, A.; Al-Hazmi, M. I. Journal of Food, Agriculture \& Environment., 2013, 1, 175-80.

131. Gowri, S.; Almeida, L.; Amorim, T.; Carneiro, N.; Pedro, S. A.; Fátima, E. M. Textile Research Journal., 2010, 80(13), 1290-306.

132. Mulqueen, P. Advances in colloid and interface science., 2003, 106(1), 83-107.

133. Herrera, N.N.; Letoffe, J.M.; Putaux, J.L.; David, L.; Bourgeat-Lami, E. Langmuir., 2004, 20(5), 1564-71.

134. Hofmann, A.F. Biochemical Journal., 1963, 89(1), 57.

135. Malakul, P.; Srinivasan, K.R.; Wang, H.Y.; Industrial \& engineering chemistry research., 1998, 37(11), 4296-4301.

136. Li, Z.; Jaroniec, M.; Chemistry of materials., 2003, 15(6), 1327-33.

137. Balaras, C.A.; Droutsa, K.; Argiriou, A.A.; Asimakopoulos, D.N. Energy and buildings., 2000, 31(2), 143-54.

138. Nelson, J.K.; Hu, Y. Journal of Physics D, Applied Physics., 2005, 38(2), 213.

139. Campanella, R.G.; Weemees, I.; Canadian Geotechnical Journal., 1990, 27(5), 557-67. 